\title{
Measuring entrepreneurial quality in southern Europe
}

\author{
Francisco Javier Santos-Cumplido*
}

Department of Applied Economics I.

School of Economics and Management, University of Seville.

Av. Ramón y Cajal 1, 41018 - Sevilla (Spain).

Tel.: +34.954.557.641, Fax: +34.954.551.636

fjsantos@us.es,

\section{Francisco Liñán}

Department of Applied Economics I.

School of Economics and Management, University of Seville.

Av. Ramón y Cajal 1, 41018 - Sevilla (Spain).

Tel.: +34.954.554.487, Fax: +34.954.551.636

flinan@us.es 


\title{
Measuring entrepreneurial quality in southern Europe
}

\begin{abstract}
The main objective of this paper is working out an empirical methodology to measure the quality of the entrepreneur's booster function, so that policy makers have an appropriate diagnosis of the qualities of entrepreneurs in their area. In this sense, two essential elements are the construction of an explanatory model, and the establishment of an entrepreneurial typology with respect to quality levels. This methodology is then applied to determine the quality level of entrepreneurs in Seville province (southern Spain), using Partial Least Squares estimation technique on a survey of 278 entrepreneurs from various activity sectors and with firms of different sizes.
\end{abstract}

JEL: C52, C87, L25, M13, M21, R11. 


\section{Measuring entrepreneurial quality in southern Europe ${ }^{1}$}

One of the questions raising greater interest among economists, at least since the beginning of the de-colonization process after the Second World War, is the debate about the factors determining income differences among countries (Hunt, 1989). In this sense, answers have usually been looked for on the basis of so-called top-down models, for which the key for economic development is factor mobility, basically that of capital and labor (Hansen 1980). According to these models, backward regions would solve their economic problems, on the one hand, by receiving capital surpluses from more advanced regions and, on the other hand, by facilitating the transfer of their manpower surplus towards those more developed regions, where they may be needed (Cappellin, 1992). This development will be spontaneous or induced and spread over time to the rest of the spatial system from relatively dynamic sectors and geographic clusters (Rosenstein-Rodan, 1943; Nurkse, 1952; Rostow, 1953; Lewis, 1955; Perroux, 1955; Myrdal, 1957; Hirschman, 1958).

Nevertheless, practice has demonstrated that income differences among regions within a country and among regions of different countries have not varied significantly during the last twenty years, at least, in the European Union (Tondl, 2001; Cuadrado, 2001)². An obvious example is the Spanish case. In spite of an improved situation in the most backward regions (Communities) -such as Andalusia or Extremadura-, they have not significantly changed their relative position with respect to the most developed Communities (Cuadrado, Mancha and Garrido, 1998; Goerlich and Mas, 2002; Garrido, 2002). Although the policy of transfers to families and to productive sectors has prevented a greater 
backwardness of the poorer regions within an ever increasing competitive context, its results have been insufficient.

In this sense, alternative models to explain economic disparities began to be elaborated from the eighties within regional development economics; these are the "Bottomup" models or "development from below" (Stohr and Taylor, 1981; Stohr 1990). According to them, the basic problems of backward economies reside in the under-utilisation of their endogenous resources, within which dynamic entrepreneurs play an outstanding role (Cappellin, 1992; Vázquez Barquero, 2002). For this reason, the promotion of productive activities through the support to local entrepreneurs is greatly recommended as an economic policy measure, with the basic objective of promoting an entrepreneurial culture (Cross and Payne, 1991; Gibb, 1993a).

Based on this importance attributed to the entrepreneur in economic development, researchers try to explain the behaviors of entrepreneurs and whether they are effectively promoting economic development in their regions. The present paper lies precisely within this line of research and has the following objectives:

- Firstly, to present a theoretical and conceptual model of the factors defining the quality of entrepreneurs in a certain region, understanding as entrepreneurial quality not management quality, but that of the behaviors that entrepreneurs perform when trying to energize their enterprises.

- Secondly, the paper works out an empirical methodology to measure the quality of the entrepreneurs' booster function, which allows us to diagnose the qualities of entrepreneurs in an area. This task is very important for the elaboration of effective policies to promote entrepreneurship. As an example, this methodology is applied to determine the quality level of entrepreneurs in Seville, a province which belongs to 
Andalusia (southern Spain), one of the most backward regions in the context of the European Union.

\section{A THEORETICAL AND CONCEPTUAL MODEL FOR ENTREPRENEURIAL} QUALITY

Although the entrepreneur's role in economic development was not given enough importance until the endogenous development approach began to be considered in the eighties, some outstanding contributions regarding their functions already existed before, such as those of Cantillon, Say, Schumpeter or Knight (Redlich,1949a; Hoselitz, 1971; Hebert and Link, 1989). But probably other social sciences have studied the entrepreneur's role more deeply before endogenous development models arose. In this sense, Weber's sociological contribution (Weber, 1969), Sombart's historical one (Sombart, 1993), or McClelland's psychological one (McClelland, 1961), may be highlighted.

All these theories, though highly valuable, have been developed without considering each other. Therefore, a wide variety of notions coexists about the functions the entrepreneur carries out to promote entrepreneurial success and, through it, economic development (Hebert and Link, 1989). In this sense, several efforts have been made in the last twenty years to reach a synthesis (Blaug, 1983; Suarez Villa, 1989; Barreto, 1989; Hebert et al., 1989; Binks and Vale, 1990; Casson, 1991; Wennekers and Thurik, 1999; Veciana, 1999). Guzmán (1994) summarized the different entrepreneurial functions pointed out by economists and other social scientists in three different ones: capitalist or financial function, carried out by the entrepreneur when supplying capital to the enterprise; the managerial function, consisting on direction, organization, negotiation, or controlling the operations of the venture; and the booster function, which implies the adoption of a series of essential 
initiatives not only to initiate the enterprise, but also to help it survive market forces and achieve expansion.

Contrary to the managerial and financial functions, the booster one has a markedly dynamic character and it is very difficult to formalize. Its result does not depend on the application of certain technical knowledge about management, however complex it may be (this corresponds to the managerial function). Rather, it depends on the qualities -both psychological and sociological- of the entrepreneur, who should decide the basic initiatives to undertake within the business such as, for example: to develop a new innovative project, to look for new profit opportunities in the market or to stay alert about possible demand changes (Redlich, 1949b; Blaug, 1983) ${ }^{3}$. As it will be pointed out later, the performance of the booster function would be the consequence of the cognitive creative process which some scholars nowadays are focusing on to explain how the process of opportunity recognition and new venture creation is carried out by potential entrepreneurs and by consolidated entrepreneurs (Gartner, 1985; Kirzner; 1997; Shane, 2000; Lumpkin, Hills and Shrader 2001; Timmons, 2004)

In this sense, it is necessary to distinguish between the two great sub-functions that, in our opinion, compose the booster function (Guzmán 1994):

- The "promoter sub-function" which entrepreneurs carry out when they create a new business. Therefore, it clearly concerns those "potential entrepreneurs" that have not still created a venture but present a high propensity to do it.

- The "energizer sub-function" which entrepreneurs carry out during the life or existence of the enterprises, promoting their development or, at least, keeping them alive. Thus, this sub-function directly concerns the work of "active or existing entrepreneurs". 
Both sides of the booster function could be a clear consequence of what has been called "the entrepreneurial culture" of a society; that is, the set of values, beliefs and attitudes towards the entrepreneurial activity of the population (Gibb, 1993b), which may directly influence the push towards the economic development of any region. In this sense, the new regional development policy based on endogenous development models, directs some instruments to improve the entrepreneurial culture, facilitating the work of local entrepreneurs (Vázquez Barquero, 2002).

Nevertheless, with respect to the energizer sub-function, that entrepreneurial culture would be manifest in the existence of entrepreneurs with certain qualities, both psychological and sociological, i.e., through a certain "entrepreneurial quality". This quality should not be confused in whatever case with management quality (which refers to activities of the managerial function and, therefore, routine functions $)^{4}$, but rather it refers to the initiatives and behaviors of entrepreneurs to energize their businesses. In this sense, a model is required to explain which are the essential features that would explain their behaviors and which would be the factors that influence them, to thus more precisely define what is meant by "quality entrepreneur" (or "dynamic entrepreneur"). We would, then, have a theoretical reference framework to allow qualitative analysis of entrepreneurs in any region.

Therefore, based on the literature about entrepreneurial functions, a model that brings together the characteristics that would define a "quality entrepreneur" and the environmental factors that would influence these characteristics can be found in Guzmán and Santos (2001) and Santos (2001). This model follows the tradition of other eclectic theories which consider entrepreneurship as a multidimensional concept where the influence of sociological, institutional, political and personal factors are essential in the behavior of entrepreneurs and in their relationship with economic growth and development (Reynolds, Hay and Camp, 1999; Audretsch, 2002; Verheul, Wennekers, Audretch and Thurik, 2003). Among the 
elements which configure "entrepreneurial quality", there are three of them in that model: the preference to work as self-employed, the entrepreneurial motivation and the energizer behaviors (Figure I):

a) Preference to work as self-employed: This personal characteristic is an alternative way to refer to the need of independence alluded to by Collins and Moore (1964) or autonomy alluded to by Cromie and O'Donaghue (1992). Thus, preference to work as self-employed could be considered as the most clear characteristic of an entrepreneur. However, this personal feature does not belong only to the entrepreneur, since it can also be present in other individuals to a similar degree, such as teachers or artists, for example. In this sense, it could be considered as a necessary condition, but not sufficient, to be a quality entrepreneur. b) Entrepreneurial motivation: motivation is the set of factors that surround or influence the performance of a given behavior in a specific situation. Entrepreneurship intentional models are the base of this important psychological characteristic (Krueger and Casrud, 1993; Krueger and Brazeal, 1994; Krueger, Reilly and Carsrud, 2000; Krueger, 2003), although, the literature shows in recent years a growing, wide and differentiated interest in it (such as for example, Shane, Locke and Collins, 2003). Among different taxonomies of motivations, the one which differentiates the intrinsic/extrinsic type is very interesting. The intrinsic/extrinsic motivation taxonomy considers the importance of the cognitive process and, therefore, the qualities of the individual. Intrinsic motivation is close to the need for achievement referred to by McClelland (1961). An intrinsec entrepreneurial motivation means that the entrepreneur's activity is developed not to win an economic reward, but by the interest and pleasure of carrying it out (vocation, need for personal development) and the extrinsic entrepreneurial motivation means the opposite ${ }^{5}$.

c) Energizer behaviors: The performance of different energizer behaviors could show the quality level of entrepreneurs because they would drive their actions to improve or not the 
performance of the business. These behaviors are derived from four dimensions of entrepreneurial orientation:

- Ambition, which can be understood as the need of the entrepreneur to develop the business through different investments in new production resources (fixed assets or manpower), through taking risks and showing competitive aggressiveness (McClelland, 1961; Davidsson, 1991; Lumpkin and Dess 1996). As Davidsson (1991) says "Just as founding a firm is considerd more entrepreneurial than not doing so, pursuing continued development of the firm is the more entrepreneurial choice when refraining from doing so is another feasible alternative”

- Innovation, which can be understood in a wide sense as Schumpeter's five new combinations, that is to say, as creativity (Schumpeter, 1944; Hagen, 1962; Lumpkin and Dess, 1996). Innovation reflects an entrepreneur's tendency to engage in new ideas, novelty and creative processes such as technological or product-market innovations. Nonetheless, imitation, which is a kind of innovation characterized by a low degree of creativity, can be included, although it is very important in the same way to force radical innovators to create new ideas again (Baumol, 1990 and 2004).

- Cooperation, which can be understood as the behavior of search for contacts with other people, entrepreneurs or not, and different organizations with the intention of reinforcing the competitive position of the firm in the market and reach a higher degree of growth. The behavior of cooperation could be formal, through agreements with other businesses in the same or related activity sectors. This helps small firms to increase their size without losing their great flexibility (Costa and Callejón, 1992). Nevertheless, cooperation can be informal, through personal social networks which are very important as much in the pre-startup stage of the business as in that of business startup and ongoing business stages (Butler and Hansen, 1991; Curran et 
alia 1993; Monsted, 1995; Johannisson, 1995). From a macroeconomic point of view, empirical researches on the success of Italian industrial districts (Pyke et alia, 1992; Markussen, 1996; Guerreri et alia, 2001) and the development of the theory of clusters during recent years (Porter, 1991 and 1998) highlight the importance of formal and informal cooperation in a globalized world economy.

- Proactiviness or leadership (Lumpkin and Dess, 1996; Gupta, MacMillan and Surie, 2004) which refers to a behavior aimed at anticipating and acting on future needs through taking different dynamic initiatives in an effort to energize the business. This behavior would be the opposite of passiveness, that is, indifference to leading in the market. A problematic point with proactiveness is that it could be closely related to innovation or ambition so it would be difficult to specify which could be the way to measure it. Nevertheless, some behaviors, such as seeking money to invest, investing in the training of employees, or putting into practice long-term planning of activities, could be a way to identify proactiveness because all of them are dynamic actions whose objective is to energize the firm.

These entrepreneurial qualities, in the model, would be influenced by environmental factors, which can be divided into two types. On the one hand, factors of the entrepreneur's personal environment, which would be basically family, education and professional experience (Cooper and Dunkelberg, 1987; Scherer, Brodzinsky and Wiebe, 1991; Herron and Robinson, 1993; Krueger et al., 1993; Gibb, 1993; Ray, 1993; Krueger, 2003). On the other hand, factors of the entrepreneur's global environment, among which would be productive opportunities, sociocultural and political-institutional factors (Wilken, 1979; Van de Ven and Garud, 1989; Shane, 1994; Gnyawalli and Fogel, 1994; Davidsson, 1995; Tiesen, 1998; Aldrich and Martinez, 2003). Thus, while personal environment factors 
provide entrepreneurs with abilities and attitudes, global environment factors provide opportunities, values and information.

Obviously, important interrelations exist among the different elements of the model (Figure I), with the following ones standing out (Guzmán and Santos., 2001):

- Intrinsic entrepreneurial motivation or innovative motivation can exercise a direct influence on booster/energizer behaviors (Ajzen, 1991; Krueger and Casrud, 1993; Kuratko, Hornsby and Naffziger, 1997; Vivarelli, 2004). An intrinsic motivation would contribute to a greater extent to the adoption of appropriate energizer behaviors. This is because people with this kind of motivation try to do more difficult tasks, reach a greater conceptual learning, strenghthen their creativity, are more persistent in their behaviors and, finally, have more inclination to positive emotions (Velaz Rivas 1996).

Insert Figure I about here

- The impact of entrepreneurship on economic growth and development is a topic that has emerged from the empirical point of view quite recently within the field of entrepreneurship (Acs, 1996; Reynolds et al., 1999; Wennekers et al., 1999; Audretsch and Thurik, 2001; Carree and Thurik. 2003). In this sense, the type of energizer behaviors defined in our model (ambition, innovation, cooperation and proactiveness) would influence entrepreneurial success or failure and, in turn, this 
would influence a higher or lower level of economic growth in the area where entrepreneurs operate through the performance of firms.

- Environmental factors can affect -directly or indirectly- the necessary condition, the motivation and the energizer behaviors. In turn, feedback processes exist: on the one hand, the incidence of development levels on the factors of the entrepreneur's global environment; and, on the other hand, the incidence of the level of entrepreneurial success in the factors of the personal environment.

As a result, the different elements of the theoretical model of entrepreneurial quality have a circular relationship. The interdependences among those factors are numerous and, therefore, any change in one of them would have an influence on the rest. In this sense, if policy-makers want to implement quality policies to promote entrepreneurship in a specific location, it is necessary to know the nature and intensity of those relationships. However, to fulfill this task, it is also necessary to have a clear empirical methodology.

\section{METHODOLOGY AND DATA}

Starting from the theoretical and conceptual model, the application of an empirical methodology would be carried out through an empirical study. So, we decided to analyse Seville entrepreneurs because, within Andalusia, the interest towards regional economic development has notably grown in the last few years, due to its lower development level relative to the rest of Spain and other regions of the European Union (Cuadrado, 1998; Tondl, 2001; Rus and Rastrollo, 2001). As mentioned above, to deepen our knowledge about the characteristics of entrepreneurs in this southern european region would be essential as a previous and very important task to elaborate effective policies to promote entrepreneurship.

An essential problem to be solved when analyzing the entrepreneurs' qualitative characteristics is the absence of specific databases and, therefore, of information about those 
characteristics. This problem is largely related to the almost nonexistent tradition -at least in Spain- of carrying out studies about entrepreneurs' qualitative aspects, either from the theoretical or the empirical viewpoints. Therefore, to solve this problem, it is known that field studies using personal interviews with a representative sample of local entrepreneurs are needed. The methodology for collection and treatment of the information must include three important tasks: a clear definition of the target population, elaboration of a simple and clear questionnaire and, finally, a statistical treatment of data through the elaboration and indexing of entrepreneurial quality with the use of an exploratory and structural statistical model.

In this empirical study, the target population is defined by the following characteristics: a) the object of analysis was real people, i.e., the entrepreneurs; b) these people possessed -at least- a relevant enough share in the capital to allow them to be considered as owners; c) the enterprise was located and developed its activity in the studied area, neglecting those that simply are branches or plants of large national or foreign companies; d) self-employed persons without employees were excluded, since a minimum level of consistency and size of the productive unit is needed; e) the entrepreneurs had to be involved in the management and control of the business, and not simply obtaining an income in the form of profit. Therefore, the object of this study is the true autochthonous entrepreneurs, excluding those from elsewhere.

Specifically, the Social Security system database of Andalusian enterprises supplied and pared down by Díez de Castro (1995) was used as a reference in this study. From this, a randomly-selected sample of 278 firms with identifiable entrepreneurs could be extracted. This sample size was not very different to those used in similar studies carried out in Spain (Sanchis, Picó and Olmos, 1989; Guzmán, 1995; Toribio, 1998). Table I summarizes the main sample characteristics in the empirical study of quality entrepreneurship in Seville. 
Insert Table I about here

To build the questionnaire, although closed answers probably implied a loss of valuable information, they served to speed up responses, helped to better define and specify those answers and allowed interviewees to confront the questionnaire in a more relaxed way, -as they knew roughly the time they would spend on its completion. On the other hand, a general attitude of mistrust with respect to revealing any type of information was also found among Seville entrepreneurs. This tended to be much greater when questions concerned economic-financial aspects. In this sense, personal interviews served to overcome the problem of mistrust. They were usually arranged beforehand by telephone and, sometimes, given the difficulty in contacting entrepreneurs, by visiting them without warning.

The theoretical and conceptual model to be tested assumes that the effective performance of energizer behaviors (that is, the external behaviors showing the entrepreneurial quality level) should be determined by four elements -as presented in the previous section about the theoretical model. These elements are the following: preference to work self-employed (or desire for independence), type of motivation, personal environment and global environment. However, the influence of this last factor is difficult to test here as the sample comes from a single economy. By definition, the global environment in the province of Seville has to be the same for all firms operating there. Nevertheless, demographic characteristics of the person may have an influence on the variables used to 
measure the personal environment. Those demographic variables, as we will see in the results, could show the influence of some elements of the global environment, such as culture or social factors.

Therefore, the model to test here will be a simplified version of the conceptual model explained in the previous section. Thus, the performance of Entrepreneurial Quality in Seville would be firstly determined by two kinds of constructs: personal environment factors and cognitive factors (desire for independence and type of motivation). Regarding the latter, it is necessary to differentiate between intrinsic and extrinsic motivations. As was said in the previous section, the desire of independence is shown by the willingness of the entrepreneur to work self-employed. On the other hand, the personal environment of the entrepreneur will be measured via three constructs: education, professional experience and family support. These three personal elements would be acting directly on the level of quality, but also on the previous elements of the model, as shown in Figure I. Finally, the empirical model will try to test the influence of some demographic variables (age, gender, location, entrepreneur parents) on factors of personal environment, such as measures of culture or social attitudes.

An important problem with the methodology is that the conceptual model was not fully developed before the data collection and, therefore, the selection of indicators to measure the energizer behaviors which configure entrepreneurial quality is less than ideal. This means that results presented here can not be interpreted as an accurate and rigorous test of the model. Nevertheless, four partial indexes, accounting for each of the energizer behaviors identified in the previous section, were used. In all four instances, those partial indexes range from 0 to 2 , depending on the performance of the specific behaviors considered in each of them:

- Ambition index. To define this variable the answers to two of the questions have been used: whether entrepreneurs have enlarged their enterprise with investments in new 
production resources (fixed assets and manpower) in the previous three years; and whether they have thought about enlarging it in the following year. If none of either behaviors is performed, this index would present a value of 0 . The highest ambition level would be presented by those interviewees who perform both behaviors, who would be assigned a value of 2 .

- Innovation index. Innovative activity can be quite wide (Shumpeter, 1944), so diverse possibilities must be considered. Three specific indicators have been included: having introduced new products or services for costumers in the previous three years; thinking of introducing them in the following year; and carrying out export activities (as a measure of the search for new markets in the way Schumpeter explained). Each behavior is valued $2 / 3$, so that the index ranges from 0 (none of them is performed) to 2 (the 3 behaviors are performed).

- Collaboration index. The collaboration capacity of entrepreneurs is, probably, the most difficult quality to measure, so two types of behavior have been included. The first and more obvious of them consists in having established some kind of formal agreement with other enterprises of the same activity. However, the use of cooperation networks beyond mere relationships with clients and suppliers is also considered. We specifically consider the use of "communication networks" as the usual means of information for the enterprise. The index will move from 0 (none of the behaviors performed) to 2 (the entrepreneur performs both of them).

- Proactiveness index. The behaviors derived from the proactive capacity can also be, in principle, very diverse. However, those entrepreneurs who show initiative when writing detailed short-term plans or providing training for their employees have been selected. Again, this index may range from 0 to 2. 
To test this theoretical and conceptual framework, a statistical model is necessary. In this empirical study, Partial Least Squares (PLS) has been used for the analysis ${ }^{6}$. This statistical model is a multivariate technique for testing structural models (Wold, 1985). In this way, we have been able to simultaneously test all the hypothesized relationships among the variables. PLS is more adequate than covariance-based methods -such as LISREL- when the model is highly complex, the sample size is relatively small, and the analysis is exploratory (Gefen, Straub and Boudreau, 2000; Roldán and Leal, 2003). In particular, PLSGraph software has been used (Chin and Frye, 2003).

With regard to the measurement model, as we have used single-item constructs or formative ones, the traditional item and construct reliability, as well as convergent and discriminant validity are not adequate. In formative constructs, the adequacy of indicators is given by weights, that is, the extent to which they contribute to generating the construct (statistical information is included in the appendix). As an example, weights of the four partial indexes used to measure Entrepreneurial Quality range from 0.1458 for the collaboration index, to 0.5957 for the initiative one. This would be indicating that none of them is irrelevant, and -at the same time- there is not one single indicator providing an overriding weight.

Finally, the Entrepreneurial Quality Index was obtained by combining those four partial indexes of energizer behaviors. Nevertheless, the PLS software transforms those four partial indexes into a latent variable, the Entrepreneurial Quality Index (EQI), obtaining optimal weights. This approach should be better than any set of arbitrarily chosen weights. The next section presents the main results obtained. 


\section{RESULTS}

The concrete specification of the model to be tested is presented in Figure II, alongside the results obtained. The numbers next to the arrows are the path coefficients or regression coefficients. Their level of significance (if any) is indicated in the Figure. On the other side, the numbers below endogenous constructs represent the proportion of their variance explained by the model. In particular, almost $20.0 \%$ of the variance in the Quality Index is accounted for by the explanatory variables.

Results must be considered with caution because of the fact that the conceptual model was not fully developed before the data collection. Nevertheless, there are some significative relationships that support different assumptions on which this simplified Entrepreneurial Quality model is based for the elaboration of the index.

In fact, demographic variables play a significant role in shaping the personal environment of the entrepreneur. For instance, almost half of the variance in experience is explained by age, by having entrepreneur parents and by gender. The role of age over experience is more obvious but the influence of gender shows the discrimination against women in the Seville environment. They face serious problems to be entrepreneurs, maybe due to the still traditional culture in comparison to other Spanish and European regions. The influence of family help on experience is also an important fact in the Seville environment: a great percentage of entrepreneurs have entrepreneur parents and, then, have the posibility of working in the family business from an early age.

Nevertheless, the influence of those demographic variables on family help and education level is not so satisfactory. Even so, we have found a significant relationship between age and education. This may be explained by the late implementation (in the 1980's) of a free, nationwide educational system in the country. This has had a deeper effect on the Andalusian people because of their higher percentage of illiteracy in comparison to 
the national average thirty years ago. On the other hand, location has a significant relationship on education because levels of illiteracy were in the 1970's in rural areas of Andalusia even deeper than in large cities, such as Seville. This reflected again the traditional and rural culture which existed in the region during those years.

The influence of personal environment factors on the Entrepreneurial Quality Index has a different impact according to the variable. Education plays a very significant role both in the need of independence and in determining the performance of energizer or dynamic behaviors. In this sense, the extension of education to the general population has had a very important effect on entrepreneurial quality during these last thirty years.

Yet family help and experience are not significant. In our opinion, this may be explained by two factors. In the first place, the questionnaire may not have been adequately designed to capture the influence of those variables. Secondly, the level of experience and family support may be important to explain the emergence as an entrepreneur (start-up), but not the level of entrepreneurial quality.

Finally, the cognitive elements of the model are highly related to the Entrepreneurial Quality Index. Although, it is true that the need of independence is per se an intrinsic motivation, it is interesting to test in Seville entrepreneurs its high influence on the rest of intrinsic motivations because in our model preference to work as self-emplyed (need of independence) is considered as a necessary condition (but not sufficient) to be an entrepreneur. It should be kept in mind that levels of enemployment in Seville are almost double the European Union average and, then, there are a lot of people who are entrepreneurs to escape from unemployment, though, at the same time, they would prefer salaried work. Therefore, it would be difficult (altough, of course, not impossible) for someone who has become an entrepreneur due to economic necessity to be some day a quality entrepreneur. 
On the other hand, both need of independence and intrinsic motivations exert a significant influence on the level of quality, in the sense that both kinds of variables stimulate a higher quality entrepreneurial orientation. It is important to remark at this point that motivations are at the heart of entrepreneurial quality because the opportunity recognition process would be very difficult or impossible without the role of motivations.

Insert Figure II about here

As mentioned above, the PLS-Graph software integrates the partial indexes into a global Entrepreneurial Quality Index, calculating the weights that offer best results. Figure III presents the histogram with its distribution. As may be seen, there seems to be three blocks of cases grouped around $-1.00,0.00$ and 1.50, besides a high frequency on the lower limit. However, we used Two Step Cluster Analysis procedure provided by the SPSS software to find the optimal number of clusters. This technique is designed to reveal natural groupings within a data set. In this case, as expected, it identified three clusters of entrepreneurs according to their Quality level. Table II summarizes the main features of those three Entrepreneurial Quality categories.

Insert Figure III about here 
As can be seen in Table II, there is a relatively small number of high quality entrepreneurs, which represent only $22.3 \%$ of the sample. Obviously, this level depends on the specific items used to measure each of the partial indexes. Besides, to be able to make more definite statements in this sense, a similar sample of entrepreneurs to compare our results would be needed. Nevertheless, it can be inferred with caution that the level of entrepreneurial quality is low in the province of Seville. Therefore, the low level of economic development that is also characteristic of Seville could be a consequence of this empirical result.

Nevertheless, it is true as well that regions with a higher economic development can attract high quality entrepreneurs because of the existence of institutions, opportunities or infraestructures. This reasoning is partly supported both by the theory of the new economic geography (Krugman 1991, Fujita et alia 1999) and the theory of endogenous growth (Romer, 1986). The problem with this point of view is that, as has been demonstrated in the case of Seville, the State investments (for example through the European Cohesion Funds or the organization of some international events such as Expo'92 or the World Athletic Championship in 1999), which were done to create those institutions, opportunities or infraestructures, have not significantly changed the relative position of Seville and Andalusia both in Spain and the European Union. Meanwhile, the same thing has not happened in other Spanish regions, such as Murcia, La Rioja or Navarra, or in other European regions which were also poor several decades ago. They had not enough capital, infraestructures and institutions and they were helped as Seville was helped. Nevertheless, they had simultaneously to create or to look for the opportunities to grow. In short, economic development does not always exert a direct influence on entrepreneurship (Nolan 2003). 
A problem with the results is that data do not allow us to relate the quality index with regard to some measure of the business success. Some papers, such as that of Stormer et alia (1999), connet both kind of measures but with some limitations. In particular, it is very difficult to measure business success appropriately because of the previously alluded to general attitude of mistrust of entrepreneurs with respect to revealing any information of economic or financial aspects.

Insert Table II about here

According to the Entrepreneurial Quality model, a higher level of quality would imply that the firm would be more successful and -at the aggregate level- a greater contribution to the development of the economy in which it operates. In this sense, it may be assumed that, in general, higher quality entrepreneurs, after some time, will possess larger firms, mainly because of a behavior which derives from higher levels of ambition, innovation, cooperation and proactiveness.

In table III, it can be seen that the relationship between size and entrepreneurial quality is highly significant $(\mathrm{p}<0.001)$. In particular, it stands out that $90.8 \%$ of low quality entrepreneurs (89 out of 98) own microenterprises of up to 5 employees. Therefore, despite the influence of regional and sector conditions (competition), this relationship would be indicating that firm size is a consequence of the entrepreneur's quality level in this province. It can not be forgotten that the entrepreneurial quality seems to be low in Seville and, 
therefore, the opportunity recognition process, the start up of new businesses, the success of the businesses and, finally, the growth of the regional economy would be very difficult.

Nevertheless, there are two important methodological problems with this conclusion. On the one hand, it is true that both firm expansion and the desire to undertake it are part of the quality index. In this sense, it would be better if ambition was measured using differents indicators. On the other hand, data refers to a single moment of time (cross-sectional) and to appropiateley test the asumption that entrepreneurial quality leads to firm growth, it would be necessary to do a longitudinal analysis. It would be interesting to choose a panel of small entrepreneurs, to study their entrepreneurial quality, to follow the evolution of their businesses during several years and, finally, to check if their initial qualities have exerted an influence on growth. However, this kind of analysis has also the problem that entrepreneurs who want to participate in these research experiences usually are those who are more motivated and, therefore, the ones with higher quality.

Insert Table III about here

Comparisons cannot be made so freely between firms in different sectors, as the kind of economic activity developed may be conditioning firm size. In our sample, the proportion of high quality entrepreneurs in manufacturing is $35.4 \%$. That ratio falls to $22.2 \%$ in construction and to $19.1 \%$ in services (including trade). It seems therefore, that higher entrepreneurial quality is needed to operate an industrial firm, followed by construction, and 
with trade and services as the less demanding in this respect. In fact, Pearson's Correlation among the variables Quality Index and activity sector reaches a value of -0.107 and is marginally significant $(\mathrm{p}<0.1)$. However, when the Chi-squared test was used, that relationship was non-significant.

Therefore, taking into account activity sector, we have checked whether the relationship between entrepreneurial quality and firm size still holds. Our findings indicate that this is the case, as those relationships are significant for manufacturing firms $(\mathrm{p}<0.05)$, for construction companies $(\mathrm{p}<0.01)$, and also for those in services $(\mathrm{p}<0.001)$.

Finally, with the exception of location, external variables are very weakly related to Entrepreneurial Quality. Correlation coefficients are lower than 0.070 for age, gender and parents-entrepreneurs. This would be indicating that those factors do not have a direct effect on the level of quality, but only on the configuration of the personal environment.

Nonetheless, location does have a relatively high correlation with Entrepreneurial Quality, reaching 0.204 . The interpretation of this result is not easy. Location was measured from 1 (most isolated parts of the province) to 4 (metropolitan area). In our opinion, therefore, this correlation could be revealing the influence of the global environment. In fact, one should expect the metropolitan area to present some more favorable conditions than the rest of the territory due to its greater market size, higher offer of professional services, better infrastructures -especially communication ones- and so on. Thus, this could serve as an indirect confirmation of the important role that global environment may be playing, since it shows how higher quality entrepreneurs tend to concentrate on the metropolitan area.

\section{CONCLUSIONS}

The analysis of the role carried out by the entrepreneur in the economy is still not sufficiently developed. However, this needs to be changed, as the entrepreneur occupies a 
pre-eminent role in a market economy, especially nowadays with increased competition and uncertainty as a consequence of the globalization process.

As may be seen in this paper, the analysis of the entrepreneur's behaviors is a complex issue. Firstly, it is necessary to keep in mind that such behaviors are not innate, because they are influenced by a whole series of personal, economic, social, cultural and political variables, which requires a multidisciplinary approach. Secondly, as there is not a clearly-defined population of entrepreneurs, the results derived from different analyses of the data always must be taken with caution.

Specifically to overcome this complexity, this paper seeks to advance in a methodological framework that stimulates future research in this area of knowledge. In this sense, the theoretical model adopted allows the defining of the characteristics a quality entrepreneur should possess, and the factors that influence them. Predetermination of the stages to follow within this empirical methodology to analyze entrepreneurial quality may be important, as it would allow carrying out similar studies in different economies and, therefore, comparing results, which is presently very difficult.

Within this empirical methodology, the importance of the elaboration of an entrepreneurial quality index stands out. This index, as it has been explained, would allow the obtaining of a measure of entrepreneurial quality in a certain area, grouping entrepreneurs according to their quality level, and establishing a profile for the quality entrepreneur. The results thus obtained could allow a better diagnosis and the elaboration by policy-makers of more appropriate measures to promote entrepreneurial quality.

Finally, this empirical methodology has been applied to Sevillian entrepreneurs to demonstrate its operability. Despite the problems regarding data collection and the measurement of some energiser behaviors, this application shows that both the entrepreneurial quality model and the quality index offer some results which are consistent 
with the theory. In general, results show that Seville's entrepreneurs could have a low level of quality, indicating that firm size and, maybe, sectoral specialization could be a consequence of the entrepreneur's quality level. Finally, with the exception of location, external variables are very weakly related to Entrepreneurial Quality, indicating that those factors would not have a direct effect on the level of quality, but only on the configuration of the personal environment.

Therefore, the substantial backwardness of Seville with regard to other areas in the country and the European Union could be related to the low level of entrepreneurial quality. Moreover, the implementation of policies presently applied does not seem to be contributing enough to a great improvement of entrepreneurial quality in the province and in the region because, in general, this question would not be being taken into consideration. 


\section{Notes}

1 The authors want to thank Leo Van Wissen -Netherlands Interdisciplinary Demographic Institute (NIDI) and the University of Groningen- for his hepful comments and suggestions. We are also very grateful to Wynne Chin -University of Houston- for supplying the necessary PLS software package, and also to J.L. Roldán -University of Seville- for his help with the statistical analysis.

2 The neoclassical theory of economic growth elaborated from the seminal work of Solow (1956) and Swan (1956) has been used by authors such as Barro (1991) or Sala-i.Martin (1990) to predict the convergence among countries and regions. Nevertheless, as Romer has demonstrated (Romer, 1986), the convergence is difficult or not possible because there are increasing returns in the long run due to technological spillovers and knowledge spillovers.

3 Fritz Redlich (1949b), one of the researchers who belonged to the Research Center in Entrepreneurial History of Harvard, refers to three kinds of functions in a business: the capitalist function, the manager function and, most important, by the entrepreneur function. This latter could be assimilated to the booster function. Forty years later, Mark Blaug (1989) also refers to three entrepreneurial functions: financing function, managerial function and, finally, power-decission function. This would also be connected with the booster function.

4 See for example, with regards to management quality, Azzone and Cainarca (1993). They define quality in two ways: quality in the production process (the ability to reduce or eliminate waste and sources of defective products) and quality of conformance (the respondance of a product to design specifications) and grade (the capacity of a product to satisfy customers' requirements). 
5. A different taxonomy of motivations close to the intrinsic/extrinsic type is better described in Kuratko et al. (1997). Regarding the distinction among push factors (unemployment) and pull factors (education) of motivation (Cooper and Dunkelberg, 1986), although it is also close to the former, we think it is insufficient because each variable can positively or negatively influence motivations, depending on the person.

6. Three relevant papers on entrepreneurship where Partial Least Squares is used to test a conceptual model can be found in Davidsson (1991), Chua et alia (1999) and Julien et alia (2003). 


\section{References}

Acs, Z.J. 1996. Small firms and economic growth. In P.H. Admiraal (Ed.). Small business in the modern economy. De Vries lectures in economics: 1-62. Oxford: Balckwell Publishers.

Acs, Z.A. \& Audretsch, D. B. (eds). 2003. Handbook of entrepreneurship research: An interdisciplinary survey and introduction. London: Kluwer.

Ajzen, I. 1991. The theory of planned behavior. Organizational Behavior and Human Decision Process. 50: 179-211.

Aldrich, H.E. \& Martinez, M. 2003. Entrepreneurship as social construction: A multilevel evolutionary approach. In Z.A. Acs \& D. Audretsch (Eds.) Handbook of entrepreneurship research: An interdisciplinary survey and introduction: 359-399. London: Kluwer.

Ato, M. \& López, J.J. 1996. Análisis estadístico para datos categóricos. Madrid: Síntesis.

Audretsch, D.B. 2002. Entrepreneurship: A survey of the literature. Brussels: European Commission Working Paper, Enterprise Directorate General.

Audretsch, D.B. (Ed.). 2003. SMEs in the age of globalization. Cheltenham: Edward Elgar.

Audretsch, D. B. \& Thurik, A.R. 2001. Linking entrepreneurship to growth. Directorare for Science, Technology and Industry, OECD, DSTI/DOC (2001)2.

Azzone,G., \& Cainarca, G.C. 1993. The strategic role of quality in small size firms. Small Business Economics, 5: 67-76.

Barreto, H. 1989. The entrepreneur in microeconomic theory: Disappearence and explanation. London: Routledge.

Barro, R.J. 1991. Economic growth in a cross section of countries. Quarterly Journal of Economics, 106: 407-433. 
Baumol, W.J. 1990. Entrepreneurship: Productive, unproductive and destructive. Journal of Political Economy, 98: 893-921.

Baumol, W.J. 2004. Entrepreneurial enterprises, large established firms and other components of the free-market growth machine. Small Business Economics, 23: 9-21.

Binks, M. \& Vale, P. 1990. Entrepreneurship and economic change. London: McGraw-Hill.

Blaug, M. 1983. Marx, Schumpeter y la teoría del empresario. Revista de Occidente, 21-22: 117-130.

Brown, B. \& Butler, J.E. 1993. Networks and entrepreneurial development. The shadow of borders. Entrepreneurship and Regional Development, 5: 101-116.

Butler J.E. \& Hansen, G. S. 1991. Network evolution, entrepreneurial success and regional development. Entrepreneurship and Regional Development, 3 (1): 1-16.

Cappellin, R. 1992. Los nuevos centros de gravedad del desarrollo regional en la Europa de los noventa. Revista de Estudios Regionales, 33: 15-62.

Carree, M.A. \& Thurik, A.R. 2003. The impact of entrepreneurship on economic growth. In Z.A. Acs \& D.D. Audretsch (Eds.). Handbook of entrepreneurship research: An interdisciplinary survey and introduction: 437-472. London: Kluwer.

Casson, M. 1991. The entrepreneur: An economic theory. Brookfields: Gregg Revivals. (first published in 1982. Oxford: Martin Robertson).

Chin, W. \& Frye, T. 2003. PLS Graph V.3.00 (Build 1126). Houston: University of Houston.

Chua, J.H., Chrisman, J. J. \& Sharma, P. 1999. Defining the family business by behavior. Entrepreneurship, Theory and Practice, 23(4):19-39.

Collins, O.F. \& Moore, D.G. 1964. The enterprising man. East Lansing: MI Michigan State University Press.

Cooper, A. C. \& Dunkelberg, W.C. 1986. Entrepreneruship and paths to business ownership. Strategic Management Journal, 7: 53-68. 
Cooper, A.C. \& Dunkelberg, W.C. 1987. Entrepreneurial research: Old question, new answers and methodological issues. American Journal of Small Business, 11 (3): 1123.

Costa Campi, M ${ }^{\mathrm{a}}$ T. \& Callejón, M. 1992. La cooperación entre empresas: Una nueva estrategia competitiva. Madrid: Ministerio de Industria Comercio y Turismo.

Cromie, S. \& O’Donaghue, J. 1992. Assesing entrepreneurial inclinations. International Small Business Journal, 10 (2): 67-73

Cross, M \& Payne, G. (coor). 1991. Work and the enterprise culture. London: The Falmer Press.

Cuadrado, J.R. 2001. Convergencia regional en la Unión Europea. De las hipótesis teóricas a las tendencias reales. In T. Mancha \& D. Sotelsek (Coor.). Convergencia económica e integración: La experiencia de Europa y América Latina. Madrid: Ed. Pirámide.

Cuadrado, J.R., Mancha, T. \& Garrido, R. 1998. Convergencia regional en España. Hechos, tendencias y perspectivas. Madrid: Fundación Argentaria \& Ed. Visor.

Curran, J., Jarvis, R., Blackburn, R.A. \& Blach, S. 1993. Networks and small firms: Constructs, methodological strategies and some findings. International Small Business Journal, 11 (2): 13-25.

Davidsson, P. 1991. Continued entrepreneurship: ability, need and opportunity as determinants of small firm growth. Journal of Business Venturing, 6: 405-429

Davidsson, P. 1995. Culture, structure and regional levels of entrepreneurship. Entrepreneurship and Regional Development, 7 (1): 41-62.

Diez de Castro, E. (coor). 1995. La empresa en Andalucía. Madrid: Ed. Cívitas.

Fujita, M., Krugman, P. \& Venables, A. J. 1999. The spatial economy. Massachusetts: Massachusetts Institute of Technology

Garrido, R. 2002. Cambio estructural y desarrollo regional. Madrid: Ed. Pirámide. 
Gartner, W. B. 1985. A conceptual framework of new venture creation. Academy of Management Review, 10 (4); 696-706.

Gefen, D., Straub, D.W. \& Boudreau, M.C. 2000. Structural equation modeling and regression: Guidelines for research and practice. Communications of the Association for Information Systems, 4: article 7.

Genesca, E. \& Veciana, J.M. 1984. Actitudes hacia la creación de empresas. Información Comercial Española, 611: 147-155.

Gerber, M.E. 1997. El mito del emprendedor: Por qué no funcionan las pequeñas empresas y qué hacer para que funcionen. Barcelona: Ed. Paidos Ibérica.

Guerreri, P. Iammarino, S \& Pietrobelli, C. 2001. The global challenge to industrial districts. Small and Medium-sized enterprises in Italy and Taiwan, Cheltenham: Edward Elgar.

Gibb, A.A. 1993a. Small business development in Central and Eastern Europe- Opportunity for a rethink? Journal of Business Venturing, 8: 461-486.

Gibb, A.A. 1993b. The enterprise culture and education: Understanding enterprise education and its links with small business, entrepreneurship and wider educational goals. International Small Business Journal, 3 (11): 11-34.

Gnyawali, D.R. \& Fogel, D.S. 1994. Enviroments for Entrepreneurship Development: Key Dimensions and Research Implications. Entrepreneurship Theory and Practice, 18 (4): 43- 61.

Goerlich, F.J. \& Mas, M. 2001. La evolución económica de las provincias españolas, vol $i$ : Capitalización y crecimiento. Bilbao: Fundación BBVA.

Gupta, V, MacMillan, I.C., \& Surie, G. 2004. Entrepreneurial leadership: Developing and measuring a cross-cultural construct. Journal of Business Venturing, 19: 241-260. 
Guzmán, J. 1994. Towards a taxonomy of entrepreneurial theories. International Small Business Journal, 12 (4): 77-88.

Guzmán, J. \& Santos-Cumplido, F.J. 2001. The booster function and the entrepreneurial quality: An application to the province of Seville. Entrepreneurship and Regional Development, 13: 211-228.

Hagen, E.E. 1962. On the theory of social change: How economic growth begins. Cambridge, MA: Massachusetts Institute of Technology \& The Dorsey Press Inc.

Hansen, N.M. 1981. Development from above: The centre-down development paradigm. In W.B. Stohr \& D.R.F. Taylor (Ed.). Development from above or below? The dialectics of regional planning in developing countries: 15-37. Chichester: John Willey.

Hebert, R. F. \& Link, A.N. 1989. In search of the meaning of entrepreneurship. Small Business Economics, 1: 39-49.

Herron, L. \& Robinson, R.B. 1993. A structural model of the effects of entrepreneurial characteristics on venture performance. Journal of Business Venturing, 8: 281-294.

Hirschman, A.O. 1958. The strategy of economic development. New Haven: Yale University Press.

Hoselitz. Bert. F. 1971. El Nacimiento de la Teoría Empresarial, in Sengler J. (coor) El Pensamiento Económico de Aristóteles a Marshal:. 250-272. Madrid: Ed Tecnos;.

Hunt, D. 1989. Economic theories of development. An analysis of competing paradigms. New York, Harvester Wheatsheaf.

Johannisson, B. 1995. Paradigms and entrepreneurial networks: Some methodological challenges. Entrepreneurship and Regional Development, 7: 215-231.

Julien, P. \& Ramangalahy, C. 2003. Competitive strategy and performance of Exporting SMEs: an empirical investigation of the impact of their export information search and competencies. Entrepreneurship, Theory and Practice, 27 (3): 227-245. 
Kirzner, I. 1997, Entrepreneurial discovery and the competitive market process: an Austrian approach. Journal of Economic Literature, 35: 60-85

Knight, F. 1948. Risk, uncertainty and profit. London: The London School of Economic and Political Science \& Aldwich. (first published in 1921. Cambridge: Houghton Mifflin Company).

Krueger, N., 2003. The cognitive psychology of entrepreneurship. In Z.A. Acs. \& D.D. Audretsch (Eds.) Handbook of entrepreneurship research: An interdisciplinary survey and introduction: 105-140.. Londres: Kluwer

Krueger, N. \& Brazeal, D.V. 1994. Entrepreneurial potential and potential entrepreneurs. Entrepreneurship Theory and Practice, 18 (3): 91-105

Krueger, N \& Casrud, A.L. 1993. Entrepreneurial intentions: Applying the theory of planned behavior. Entrepreneurship and Regional Development, 5: 315-330.

Krueger, N., Reilly, M.D. \& Carsrud, A.L. 2000. Competing models of entrepreneurial intentions. Journal of Business Venturing, 15: 411-432.

Krugman, P. 1991. Iincreasing returns and economic geography. Journal of Political Economy. 99 (3): 483-499.

Kuratko, D.F., Hornsby, J.S. \& Naffziger, D.W. 1997. An examination of owner's goals in sustaining entrepreneurship. Journal of Small Business Management, 35: 25-30.

Lewis, W.A. 1955. The theory of economic growth. Londres: George Allen.

Lumpkin, G. T. \& Dess, G. G. 1996. Clarifying the entrepreneurial orientation to construct and linking it to performance. Academy of Management Review, 21 (1): 135-172.

Lumpkin, G. T., Hills G. E. \& Shrader, R. C. 2001. Opportunity recognition. A CEAE White Paper, Chicago: Institute for Entrepreneurial Studies and University of Illinois.

Markusen, A. 1996. Sticky places in slippery spaces: a tipology of industrial districts. Economic Geography, 72 (3): 293-313.

McClelland, D. C. 1961. The achieving society. London: The Free Press. 
Monsted, M. 1995. Processes and structures of networks: Reflections on methodology. Entrepreneurship and Regional Development, 7: 193-213.

Myrdal, G. 1957. Economic theory and underdeveloped countries. London: Duckworth.

Nolan, A. 2003. Entrepreneurship and local economic development. Paris: OECD.

Nurkse, R. 1952. Some international aspects of the problem of economic development. American Economic Review, 42: 571-583.

Perroux, F. 1955. Note sur la notion de pole de croissance. Economie Appliquée, 7: 307-320.

Pyke, F., Becattini, G. \& Sergenberger, W. 1992. Los distritos industriales y las pequeñas empresas. Vol I. Distritos industriales y cooperación interempresarial en Italia. Madrid: Ministerio de Trabajo y Seguridad Social.

Porter, M. E. 1991. La ventaja competitiva de las naciones. Barcelona: Plaza and Janes.

Porter, M. E. 1998 On competition, Boston: Harvard Business School Publishing.

Ray, D.M. 1993. Understanding the entrepreneur: Attributes, experiences and skills. Entrepreneurship and Regional Development, 5: 345-357.

Redlich, F. 1949a. On the origin of the concepts of "entrepreneur" and "creative entrepreneur"”. Explorations in Entrepreneurial History, 1 (2): 1-7.

Redlich, F. 1949b. The business leader in theory and reality. The American Journal of Economic and Sociology, 8 (3): 223-237.

Reynolds, P.D., Hay, W.M. \& Camp, S.M. 1999. Global entrepreneurship monitor 1999, executive report. London: London Business School and Babson College

Roldán, J.L. \& Leal, A. 2003. A validation test of an adaptation of the Delone and Mclean's model in the Spanish EIS field. In J.J. Cano (Ed.). Critical reflections on information systems. A systemic approach: 66-84. Hershey, PA: Idea Group Publishing.

Romer, P.M. 1986. Increasing returns and long-run growth. Journal of Political Economy, 94: 1002-1037. 
Rosenstein-Rodan, P.N. 1943. Problems of industrialization of Eastern and South-eastern Europe. Economic Journal, 53: 202-211

Rostow, W. 1953. The process of economic growth. Oxford: Clarendon Press.

Rus, G., \& Rastrollo, M.A. 2001. Capitalización y crecimiento de la economía andaluza 1955-1998. Bilbao: Fundación BBVA.

Sala-i-Martin, X., 1990. On growth and states. PhD Dissertation. Harvard: Harvard University.

Sanchis, E., Picó, J. \& Olmos, J.M. 1989. La nueva pequeña empresa de la industria valenciana. Revista Sociología del Trabajo, 5: 41-65.

Santos, F.J. 2001. La calidad del empresario sevillano. Sevilla: Ed. Sevilla Siglo XXI.

Scherer, R.F, Brodzinsky, J.D. \& Wiebe, F.A. 1991. Examining the relationship between personality and entrepreneurial career preference. Entrepreneurship and Regional Development, 3: 195-206.

Schumpeter, J.A. 1944. Teoría del desenvolvimiento económico. México: Fondo de Cultura Económica. (first published in German in 1911).

Shane, S. 1994. Cultural values and the championing process. Entrepreneruship Theory and Practice, 18 (4): 25-41.

Shane, S. 2000. Prior knowledge and the discovery of entrepreneurial opportunities. Organizations Science, 11 (4): 448-469.

Shane, S., Locke, E.A. \& Collins, C.J. 2003. Entrepreneurial motivation. Human Resource Management Review, 12: 257-279.

Solow, R.M. 1956. A contribution to the theory of economic growth. Quarterly Journal of Economics, 70 (1): 65-94.

Sombart, W. 1993. El burgués. Madrid: Alianza. (1st Published in German in 1913). 
Stohr, W.B. 1981. Development from below: The bottom-up and periphery-inward development paradigm. In W.B. Stohr \& D.R.F. Taylor (Eds.). Development from above or below? The dialectics of regional planning in developing countries: 39-72. Chichester: John Willey.

Stohr, W.B. (ed). 1990. Global challenge and local response, initiatives for economic regeneration in contemporary Europe. London: Mansell Publishing Limited.

Stohr, W.B. \& Taylor, D.R.F. 1981. Development from above or below? The dialectics of Regional Planning in Developing Countries. Chichester: John Willey.

Stormer, F., Kline, T. \& Goldenberg, S. 1999. Measuring entrepreneurship with the General Enterprising Tendency (GET) Test: criterion-related validity and reliability. Human Systems Management, 18: 47-52.

Suarez-Villa, L. 1989. The evolution of regional economies. Entrepreneurship and macroeconomic change. Nueva York: Praeger.

Swan, T.W. 1956. Economic growth and capital accumulation. Economic Record, 32: 334361.

Szarka, J. 1990. Networking and small firm. International Small Business Journal, 8 (2): 115.

Tiessen, J.H., 1998. Individualism, collectivism and entrepreneurship: A framework for international comparative research. Journal of Business Venturing, 12: 367-384.

Timmons, J. 2004. Opportunity recognition. In Bygrave, W. and Zacharakis, A. (ed) The portable MBA in entrepreneurship, 29-70, New Jersey: John Wiley.

Tondl, G. 2001. Convergence after divergence? Regional growth in Europe. Nueva York: Springer.

Toribio, M.R. 1996. Factores característicos del empresario gaditano. Políticas de fomento. Doctoral Dissertation. Cadiz: Universidad de Cádiz. 
Van de Ven, A \& Garud, R. 1989. A framework for understanding the emergence of new industries. In R. Rosenbloom \& R. Burgelman (Eds.). Research on technical innovation. Management and policy, vol 4: 195-225. Greenwich, CT: JAI Press.

Vázquez Barquero, A. 1993. Política económica local. Madrid: Ed Pirámide.

Vázquez Barquero, A. 2002. Endogenous development. Networking, innovation, institutions and cities. London: Routledge.

Veciana, J.M. 1989. Características del empresario en España. Papeles de Economía Española, 39: 19-36.

Veciana, J.M. 1999. Creación de empresas como programa de investigación científica. Revista Europea de Dirección y Economía de Empresa, 3: 11-36.

Vélaz, J.I. 1996. Motivos y motivación en la empresa. Madrid: Ed. Diaz de Santos.

Verheul, I, Wennekers, S., Audretch, D. \& Thurik, R. 2003. An eclectic theory of entrepreneurship: Policies, institutions and culture. In D. Audretsch (Ed.). SMEs in the age of globalization: 537-606. Cheltenham: Edward Elgar.

Vivarelli, M., 2004. Are potential entrepreneurs so good? Small Business Economics, 23: 4149.

Weber, M. 1969. La ética protestante y el espíritu del capitalismo. Barcelona: Ediciones Península. (first published in German in 1904).

Wennekers, S \& Thurik, R. 1999. Linking entrepreneurship and economic growth. Small Business Economics, 13: 27-55.

Wilken, P.H. 1979. Entrepreneurship. A comparative and historical study. New Jersey: Ablex Publishing Corporation.

Wold, H. 1985. System analysis by partial least squares. In P.H. Nijkamp, H. Leitner \& N. Wrigley (Eds.). Measuring the unmeasurable: 221-251. Dordrecht: Martinus Nijhoff Pub. 


\section{APPENDIX}

Partial Least Squares results

TABLE A-I

Construct weights and collineality tests

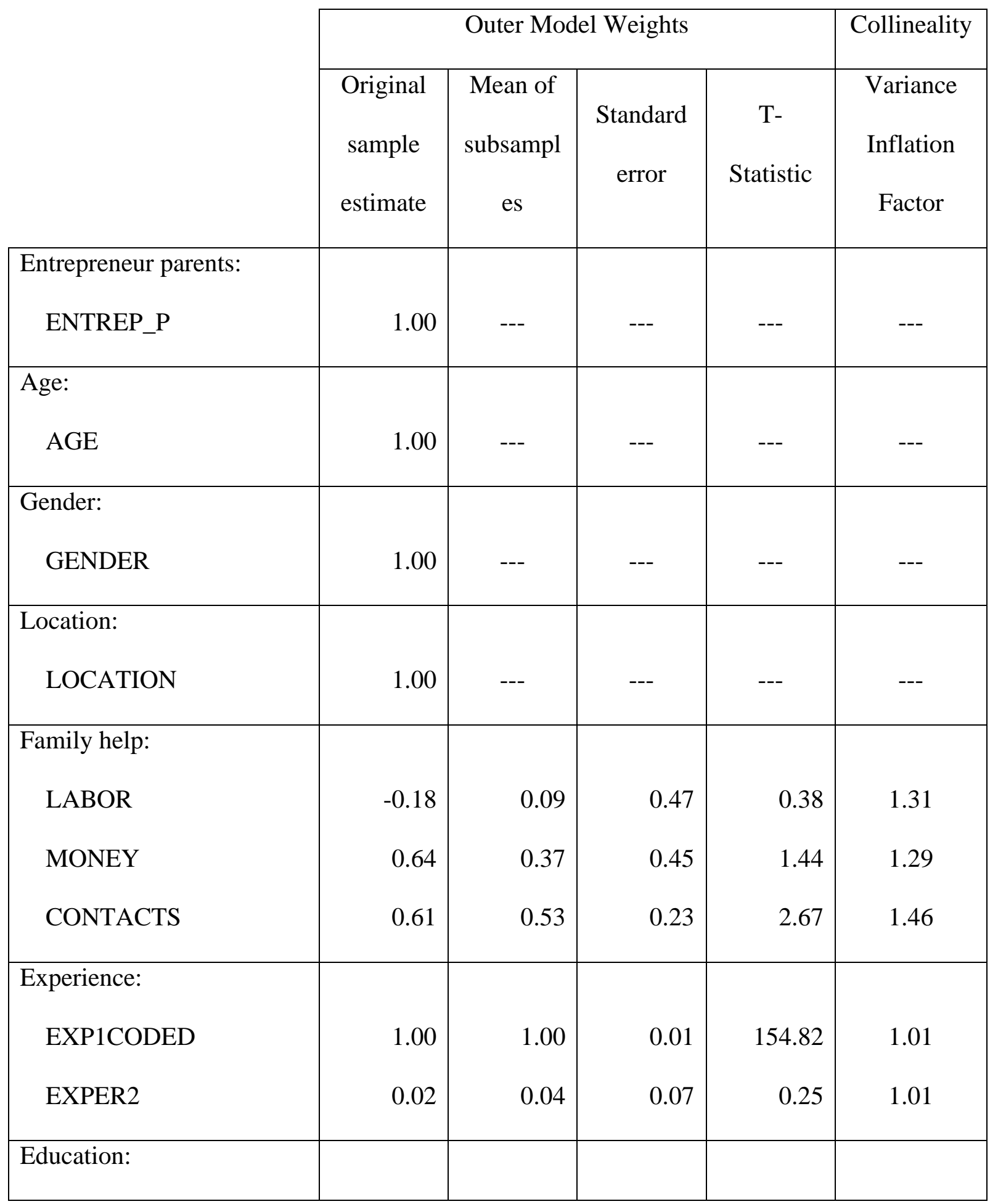




\begin{tabular}{|c|c|c|c|c|c|}
\hline EDUCATION & 1.00 & --- & --- & --- & --- \\
\hline \multicolumn{6}{|c|}{ Desire for independence: } \\
\hline DES_INDEP & 1.00 & --- & --- & --- & --- \\
\hline \multicolumn{6}{|l|}{ Type of motivation: } \\
\hline MOTIVATION & 1.00 & --- & --- & --- & --- \\
\hline \multicolumn{6}{|l|}{ Quality Index: } \\
\hline I_AMBITION & 0.40 & 0.38 & 0.21 & 1.91 & 1.22 \\
\hline I_INNOVATION & 0.20 & 0.19 & 0.15 & 1.32 & 1.26 \\
\hline I_COLLABOR & 0.15 & 0.14 & 0.14 & 1.04 & 1.21 \\
\hline I_PROACTIV & 0.60 & 0.57 & 0.18 & 3.22 & 1.34 \\
\hline
\end{tabular}


TABLE A-II

Discriminant validity coefficients

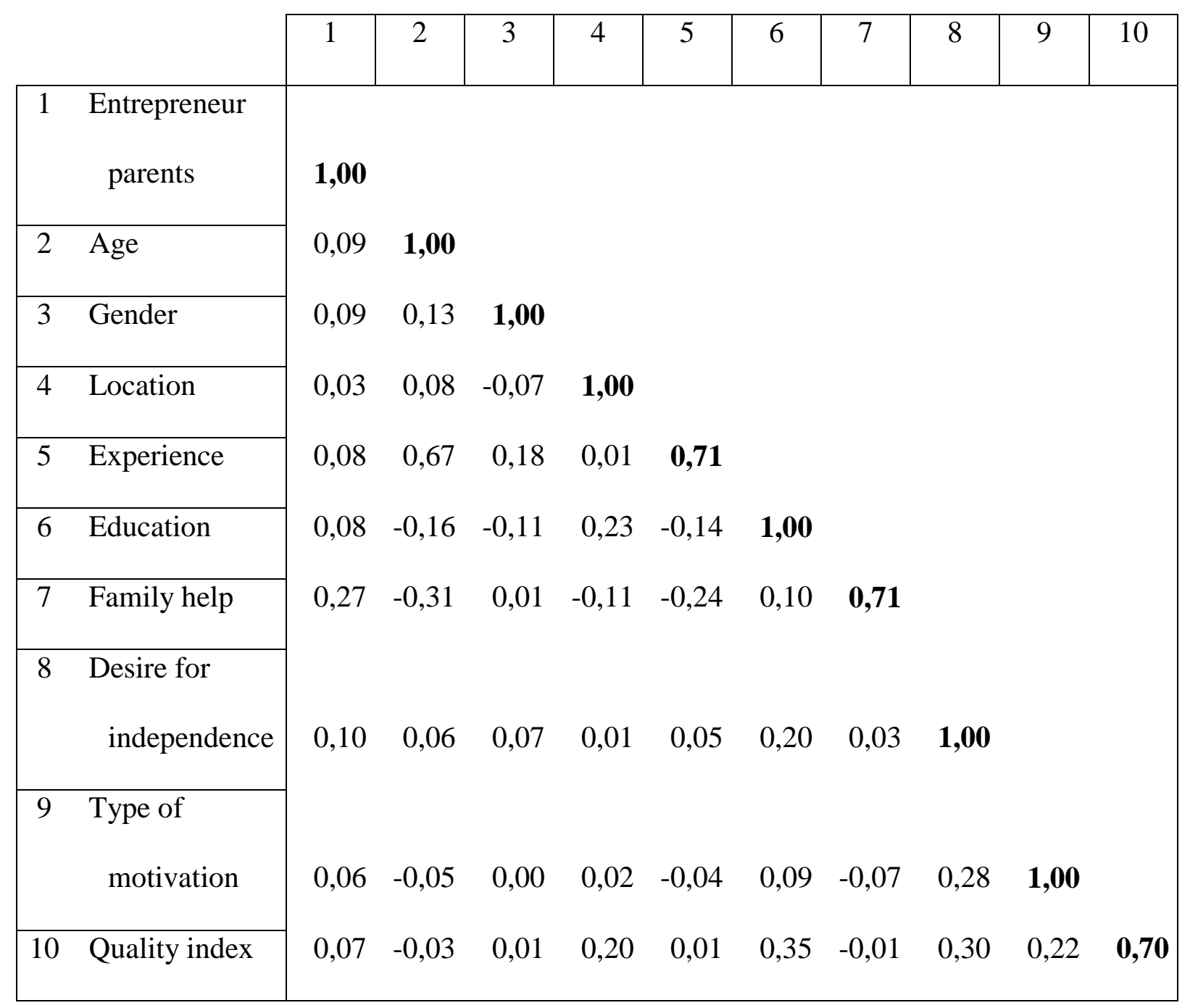


TABLE I

Sample characteristics

\begin{tabular}{|c|c|c|c|c|c|c|c|c|c|}
\hline \multirow{2}{*}{ Activity sector } & \multicolumn{6}{|c|}{ Size (No. employees) } & \multicolumn{5}{c|}{ Age } & \multicolumn{2}{c|}{ Gender } \\
\cline { 2 - 11 } & $1-5$ & $6-20$ & $21+$ & $18-25$ & $26-40$ & $41-55$ & $56+$ & M & F \\
\hline Manufacturing & 29 & 15 & 4 & - & 27 & 14 & 7 & 45 & 3 \\
Construction & 19 & 11 & 6 & - & 20 & 13 & 3 & 35 & 1 \\
Trade \& services & 154 & 32 & 8 & 9 & 90 & 75 & 20 & 167 & 27 \\
\hline Total & 202 & 58 & 18 & 9 & 137 & 102 & 30 & 247 & 31 \\
\hline
\end{tabular}


TABLE II

Grouping the Entrepreneurial Quality Index

\begin{tabular}{|c|c|c|c|c|c|}
\hline Cluster & Label & Mean value & Std deviat. & No. cases & $\%$ \\
\hline 1 & Low & -1.09 & 0.36 & 98 & 35.3 \\
2 & Medium & 0.16 & 0.37 & 118 & 42.4 \\
3 & High & 1.42 & 0.29 & 62 & 22.3 \\
\hline \multicolumn{2}{|c|}{ Total } & 0.00 & 1.00 & 278 & 100.0 \\
\hline
\end{tabular}


TABLE III

Quality level by size of the firm

\begin{tabular}{|c|ccc|c|}
\hline \multirow{2}{*}{$\begin{array}{c}\text { Quality } \\
\text { Index }\end{array}$} & \multicolumn{4}{|c|}{ Size (No. employees) } \\
\cline { 2 - 5 } & 1 to 5 & 6 to 20 & 21 to 100 & Total \\
\hline Low & 89 & 8 & 1 & 98 \\
Medium & 89 & 25 & 4 & 118 \\
High & 24 & 25 & 13 & 62 \\
\hline Total & 202 & 58 & 18 & 278 \\
\hline
\end{tabular}




\section{FIGURE I}

\section{Entrepreneurial Quality Configuration Model}

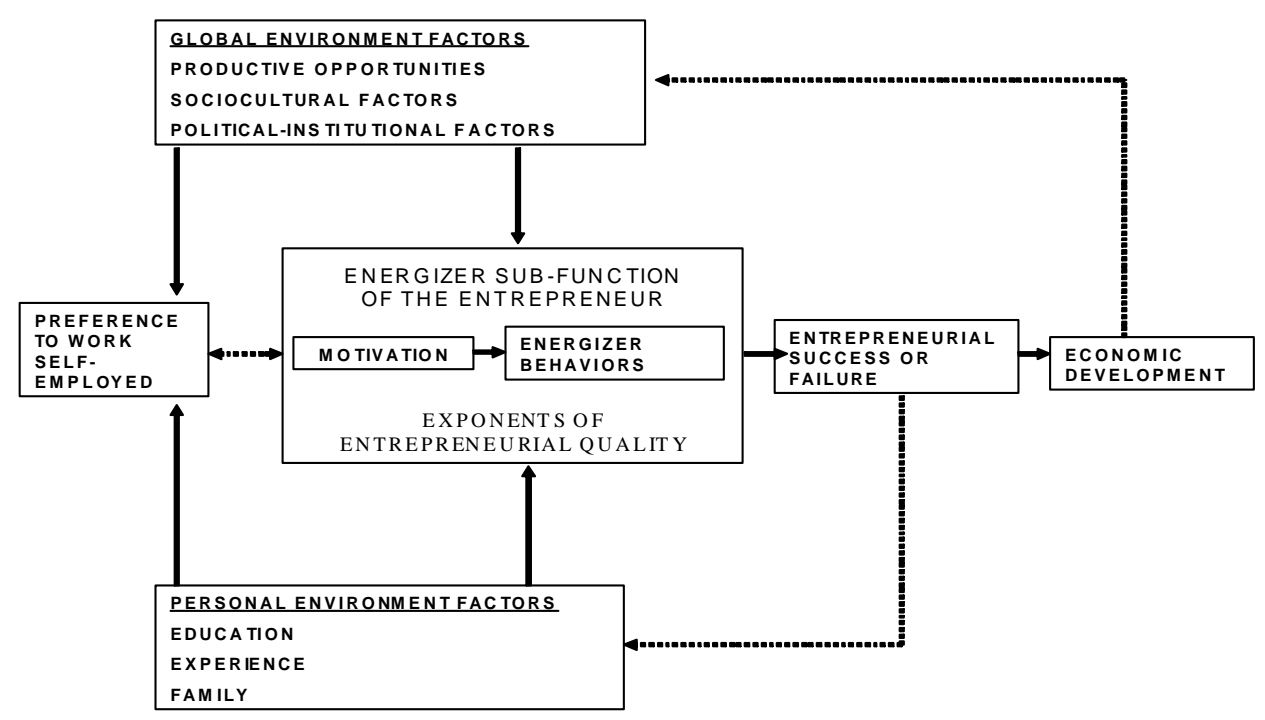

Source: Guzman and Santos (2001) 


\section{FIGURE II}

\section{Entrepreneurial Quality Index, model and results ${ }^{\mathrm{a}}$}

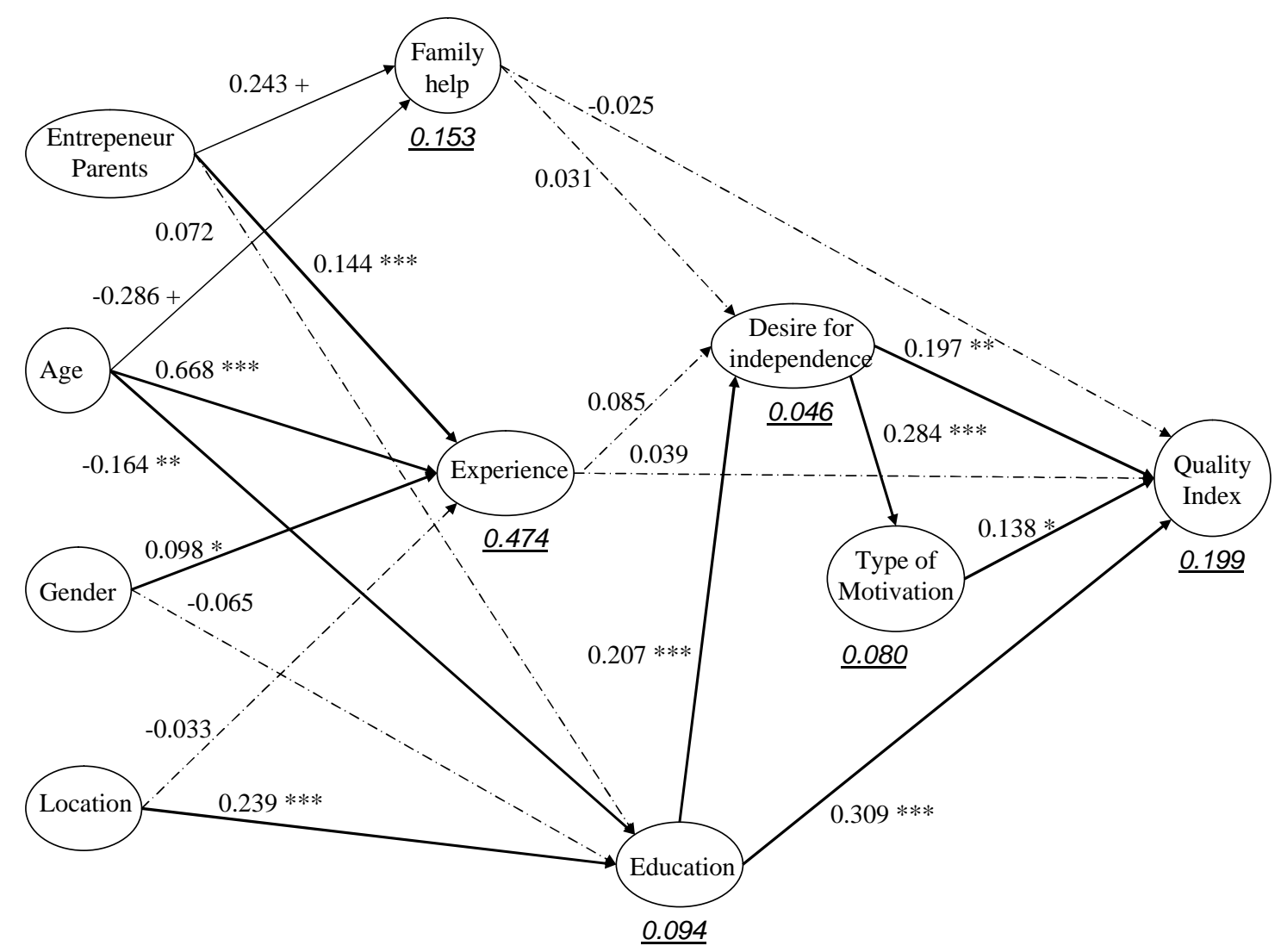

a Underlined numbers below each endogenous construct indicates the proportion of the variance explained. Numbers by the arrows represent path coefficients. Significant ones are denoted as follows:

$$
\begin{array}{ll}
+ & \mathrm{p}<0.1 \\
* & \mathrm{p}<0.05 \\
* * & \mathrm{p}<0.01 \\
* * * & \mathrm{p}<0.001 .
\end{array}
$$


FIGURE III

Entrepreneurial Quality Index histogram

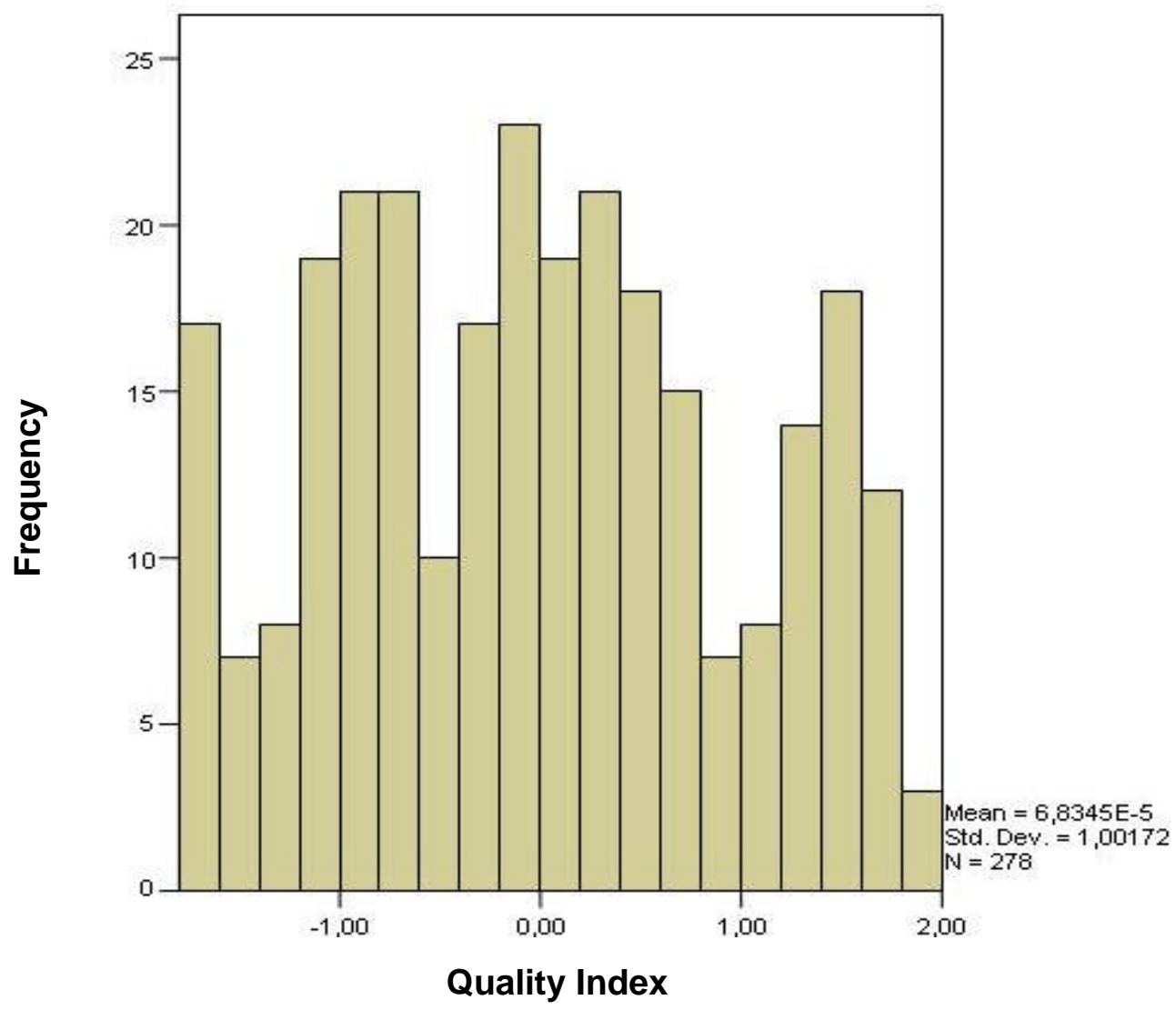

